\title{
Uliège - Faculté d'Architecture. ȘCOALA CELOR DOUĂ ȘCOLI
}

Conf. dr. arh. Melania Dulămea

melania.dulamea@uauim.ro

\author{
ULIÈGE \\ LIÈGE, BELGIA \\ $12 / 05 / 2019-21 / 05 / 2019$
}




\section{INTRODUCERE}

Belgia este un spațiu privilegiat pentru studiul arhitecturii, fapt datorat deopotrivă unei mari densități de școli de arhitectură (majoritatea universităților și colegiilor din Flandra și din Valonia incluzând domeniul în oferta lor educațională) și unei deschideri internaționale speciale, ceea ce atrage un număr mare de studenți străini.

În acest peisaj educațional dens, Facultatea de arhitectură din Liège este una dintre ultimele facultăți care s-au alăturat Universității Liège, fiind creată prin unirea în 2010 a două institute superioare de arhitectură: Institutul Lambert Lombard și Institutul Saint-Luc. Facultatea utilizează și în prezent fostele sedii ale acestor institute, atelierele desfășurându-se în două amplasamente din centrul orașului numite Botanique și OutreMeuse (Fig. 1).
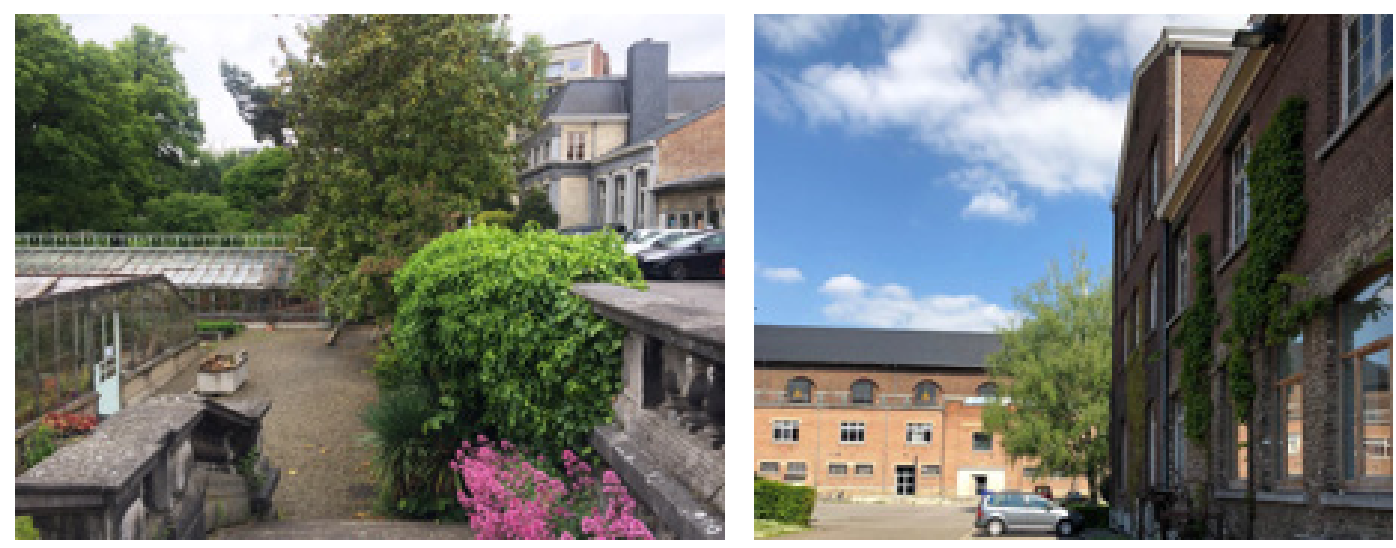

Fig. 1. Sediul Botanique (stânga) și sediul Outre-Meuse (dreapta) - imagini din arhiva personală

Tânăra facultate de arhitectură încă profită de sinergia obținută prin reunirea experienței de predare a celor două institute dar și de structurile didactice și de cercetare ale acestora. Se pare că, la 10 ani de la această unificare, identitatea celor două structuri se regăsește încă puternic în interiorul școlii și generează nuanțe de abordare a actului didactic. Până și cele două sedii oferă experiențe spațiale diferite: primul, o frumoasă clădire neoclasică cu vaste spații de ateliere orientate către grădina botanică, cel de-al doilea sediul unei abații din secolul al XVI-lea transformate, după secularizare, în cazarmă. În scurta mea vizită am avut sentimentul unei dualități, atât spațial - tipologice cât și identitare pe care aș numi-o școala celor două școli. De dată recentă, această identitate pare să se afle într-o situație fragilă sub presiunea tot mai accentuată a mediului competițional și 
a unor impuneri de natură administrativă, ce riscă să transforme această școală ca multe altele într-un loc fără memorie.

Observațiile dezvoltate în acest articol au la bază un scurt stagiu de predare centrat pe atelier și multiple întâlniri și discuții cu profesori ai școlii. Prof. Paul Hautecler și prof. Rita Occhiuto au avut deosebita amabilitate de a mă îndruma în scurta mea vizită și de a-mi vorbi deschis cu pasiune și emoție despre istoria, calitățile și provocările cu care se confruntă școala lor.

\section{2. ȘCOALA DIN LIĖGE ȘI ȘCOALA DIN BUCURESTTI PESTE ANI. CONTEXTUL ÎN CARE A AVUT LOC DEPLASAREA}

Stagiul s-a desfășurat condensat pe perioada a 7 zile (12 -21 mai 2019) pe parcursul cărora am participat activ la câte o zi de îndrumare de atelier la anii 1, 2, 3 și 4-5, precum și la câteva susțineri de doctorat și întâlniri de lucru. Acest program mi-a permis să îmi formez o imagine despre structura didactică a școlii din perspectiva îndrumării de atelier dar și să cunosc metodele de predare specifice, să observ și să interpretez asemănările și diferențele față de școala din București. Experiența stagiului a fost anticipată și amplificată prin pregătirea și participarea mea la excursia de studii a studenților anilor 4-5 din atelierul Rita Occhiuto - Paul Hautecler ce a avut loc la București în săptămâna anterioară deplasării. Vizita ce a avut ca temă descoperirea legăturilor dintre arhitectură, politică și societate, a constat într-o serie de tururi ghidate și prelegeri despre București ca oraș ce poate fi înțeles numai în corelare cu suprapunerea momentelor istorice și influențelor politice și ideologice. (Fig. 2)
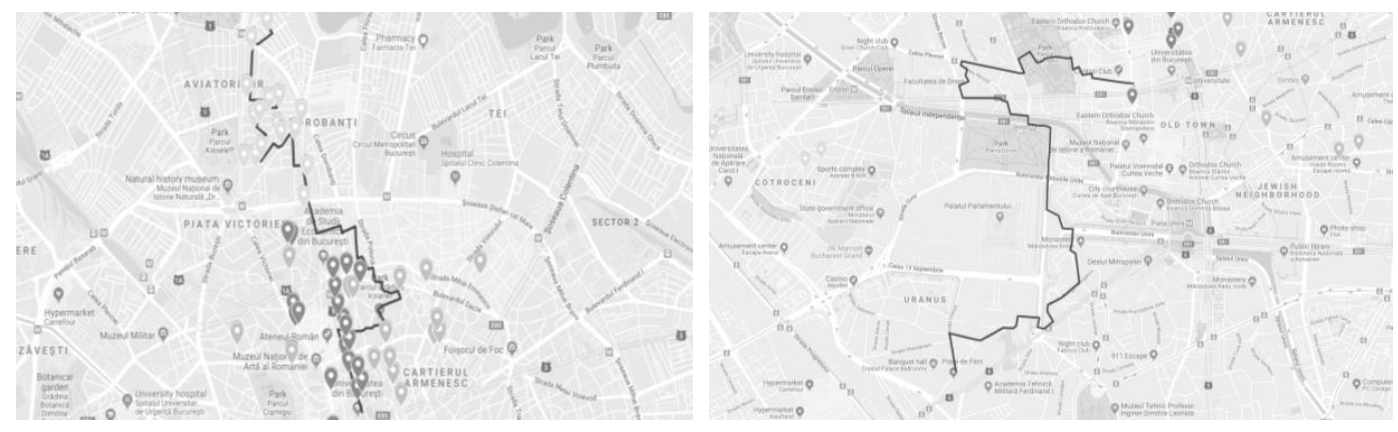

Fig. 2. Turul 1 - De la intervențiile și transformările moderniste ale țesutului orașului vechi la extinderile urbane moderniste (left map) Turul 2 - Arhitectura comunistă și orașul mutilat (right map) 
Studenții anilor 4-5 au descoperit Bucureștiul și, prin încercarea de a descifra un spațiu cultural nou și nefamiliar, au fost invitați să își privească critic propriul demers pentru proiectul aflat în desfășurare. Odată întorși în Liège au discutat în atelier cu cei doi profesori, alături de care am stat și eu, posibile implicații și dezvoltări viitoare.

Vizita mea în școala din Liège a fost întâmpinată cu gentilețe prin rememorarea, pe alocuri nostalgică, a vizitelor anterioare ale profesorilor din Mincu ce desfășuraseră stagii de predare la începutul anilor 90 în institutul Saint-Luc. Numele profesorul Dan Marin a fost rostit adesea.

\section{STRUCTURA DIDACTICĂ DIN PERSPECTIVA ATELIERULUI}

Ciclurile de licență și master oferă studenților posibilitatea de a aborda toate domeniile care ating arhitectura, atât tehnice cât și sociale, de reprezentare grafică, project management, dezvoltare urbană etc. Dintr-un total de 180 de credite, 64 sunt acordate concepției arhitecturale, 46 științelor tehnice, 28 tehnicilor de reprezentare, 16 istoriei și culturii arhitecturale, 14 concepției urbane și studiului peisajului, 12 științelor sociale. (https://www.archi.uliege.be/cms/c_5634606/fr/archi-bachelier)

Abordarea proiectului crește gradual în complexitate. în anul întâi studenților li se cere să își dezvolte creativitatea prin exerciții mai abstracte pentru ca treptat ei să fie confruntați cu diferite și complexe forme ale realității. Anul doi introduce contextul iar anul trei mută privirea la scara comunității. În ciclul de master abordarea se diversifică prin intermediul unor ateliere fixe cu tematici distincte și a unor ateliere opționale ce reprezintă domenii de specialitate: patrimoniu, urbanism și peisaj, design etc. Studenții pot alege între 6 ateliere diferite care le permit să abordeze în detaliu subiecte la scară mica, de până la 1000 mp, sau să privească la scara orașului, a teritoriului, a peisajului, prin masterplanuri sau programe complexe.

Temele de proiectare sunt intim legate de studiul orașului ca organism în continua transformare. Amplasamentele sunt situate majoritar în Liège chiar în proximitatea celor două sedii unde au loc atelierele, astfel încât studenții experimentează permanent situl în diferitele momente de evoluție ale propriului lor proiect.

La ciclul de licență proiectele se întind pe perioada unui întreg semestru, iar la ciclul de master pe perioada întregului an. Anii 4-5 sunt organizați în ateliere verticale astfel încât studenții anului 4 să învețe din experiența colegilor lor din anul superior pentru care tema atelierului ales este baza proiectului de finalizare a studiilor. 
Atelierul se desfășoară pe parcursul a 8 ore pe săptămână, grupate într-o zi în sesiuni de dimineață și după amiază cu pauză de prânz.

Interesantă mi s-a părut alternanța în structura anului universitar de perioade intensive, cu durată de circa o lună, de cursuri sau de atelier, care permite studentului un timp de reflecție și reconsiderare a demersului de până atunci. Anul universitar se încheie la toți anii de studiu cu jurizările de proiecte, accentuând astfel rolul privilegiat al atelierului.

\section{TEMATIC $\check{A}$}

La ciclul de licență studentul este introdus în proiectarea spațiului și traducerea spațială a ideilor prin dezvoltarea și utilizarea treptată a cunoștințelor și dobândește o metodologie solidă pentru dezvoltarea proiectului de arhitectură abordând întrebări din ce în ce mai complexe:

- $\quad$ anul 1 este dedicat descoperirii arhitecturii și înțelegerii și învățării limbajului ei prin intermediul mai multor exerciții ce au loc pe parcursul primului semestru. Semestrul 2 este dedicat unui exercițiu de sinteză. Pe parcursul vizitei mele era în studiu conceperea unui releu de biciclete de-a lungul rețelei Ravel (Rețeaua autonomă de căi lente);

- anul 2 integrează din ce în ce mai mulți factori: spațialitate, funcționalitate, construcție, context și integrare. Un prim exercițiu (o casă) pleacă de la analiza unei arhitecturi de referință, scoate la iveală „sensul” acesteia pentru a o reinterpreta într-un nou context urban. Al doilea exercițiu amplifică aceste noțiuni prin suprapunerea de noi date: peisajul, o schimbare de scară, o funcție publică. De exemplu, în semestrul doi când a avut loc deplasarea, studenții studiau extinderea sediului Botanique al facultății de arhitectură cu o funcțiune publică ce încorpora spații de bibliotecă în relație directă cu parcul botanic.

- $\quad$ Anul 3 abordează conceptele de spațiul public, spațiul privat și se încheie cu un proiect-sinteză prin care studentul trebuie să demonstreze integrarea unor parametri multipli: tehnic, social, de mediu, urban. Exercițiul abordat în semestrul 2 viza proiectarea locuințelor colective într-un district din Liège. (https://www. programmes.uliege.be/cocoon/20202021/formations/descr/T1ARCH01.html)

Ciclul de master debutează cu o perioadă de stagiu supravegheat de la distanță urmată de o lucrare de finalizare a studiilor ce poate fi de tip:

- cercetare: un text pe o anumită problemă sau temă, care demonstrează capacitatea studentului de a dezvolta o analiză critică și de a contribui la 
dezvoltarea cunoștințelor în arhitectură;

proiect, constând în două componente inter-relaționate: dezvoltarea și reprezentarea unui proiect legat de domeniul arhitecturii și un text reflexiv. Textul reflexiv trebuie să îndeplinească următoarele exigențe: să urmărească transformarea unei întrebări formulate în termeni arhitecturali într-o întrebare de cercetare, să explice procesul de proiectare; să pună proiectul în context, în raport cu practicile și provocările actuale din arhitectură.

Astfel, lucrarea de finalizare a studiilor valorizează legăturile dintre teorie și practică, proiectul devenind suportul unei investigații teoretice.

(https://www.programmes.uliege.be/cocoon/20202021/formations/descr/ T2UARC01.html)

Atelierul de master nivel 1 și 2 condus de Paul Hautecler și Rita Occhiuto, la atelierele cărora am participat, a avut ca temă majoră intervenția asupra siturilor abandonate sau uitate din aria metropolitană a Liège-ului. S-a urmărit studiul unor părți ale unor cartiere istorice și transformarea acestora prin repararea țesutului urban existent, reconsiderarea inserțiilor arhitecturale din anii 1970 sau conversia unor clădiri abandonate valoroase. Au fost propuse 4 amplasamente la alegere:

- Sf. Gilles / Avroy - un fragment de țesut urban constituit prin suprapunerea de straturi din perioade istorice și intervenții urbane diferite, invita la deconstrucție și reconstrucție și oferea posibilitatea pentru: renovarea clădirilor de interes patrimonial; experimentarea amestecului tipologic de locuințe (studenți, cercetători, artiști și vârstnici); introducerea de noi echipamente; reintegrarea universității (studiu și învățare) în oraș; reabilitarea străzii St. Gilles promovând porozitatea, ritmul și caracterul vechiului țesut.

- Grétry/Dérivation - un bun exemplu de palimpsest, un teritoriu caracterizat de linii de transport rapid, reziduuri de structuri rezidențiale și de infrastructuri (vechea linie de cale ferată), depozite industriale sau comerciale unele abandonate sau chiar spații libere, neconstruite.

- vârful de N al insulei Outre-Meuse, între brațele Meuse-ului și Derivației - o arie de studiu ce oferă potențialul de a completa țesutul rezidențial, dar și de a fi mărginită de apă și de a avea o vizibilitate extinsă din multe direcții de perspectivă importante pentru oraș. (extras din programul de atelier) 


\section{METODE}

Vastele spații de ateliere, atât în sediul Botanique cât și în sediul Outre-Meuse, sunt organizate astfel încât colectivele de îndrumare ale unui an de studii coexistă și împart un singur mare spațiu compartimentat prin panouri pe care studenții își expun lucrările din ziua respectivă. Această organizare spațială facilitează comunicarea între grupele de studiu pe parcursul zilei de atelier, studenții văd cum lucrează colegii lor și pot asista la discuțiile celorlalte grupuri. În anul 1 studenții lucrează permanent în atelier, așezați pe grupuri în jurul aceleași mese, iar profesorii trec pe rând și discută.

Totodată, pauza de prânz devine un moment de interacțiune între profesori. în mod firesc toate colectivele de îndrumare își întrerup discuțiile la aceeași oră, iau prânzul împreună și se bucură de acest moment pentru a discuta informal și a dezbate probleme legate de școală. Aceste întâlniri sunt momente de normalitate și coeziune benefice.

Îndrumarea anilor 1, 2 și 3 favorizează lucrul individual pe machete de studiu și de context și desenul de mână. (Fig. 3) Se pune accentul pe asumarea și argumentarea demersului propriu fiecărui student prin chestionarea permanentă a setului de întrebări la care studentul a încercat să răspundă și a modului în care soluția propusă răspunde la aceste întrebări. Nu se oferă soluții ci studentul este invitat să testeze permanent variante alternative și să înțeleagă în ce mod o anumită alterare a premiselor conduce la o alterare a formei.

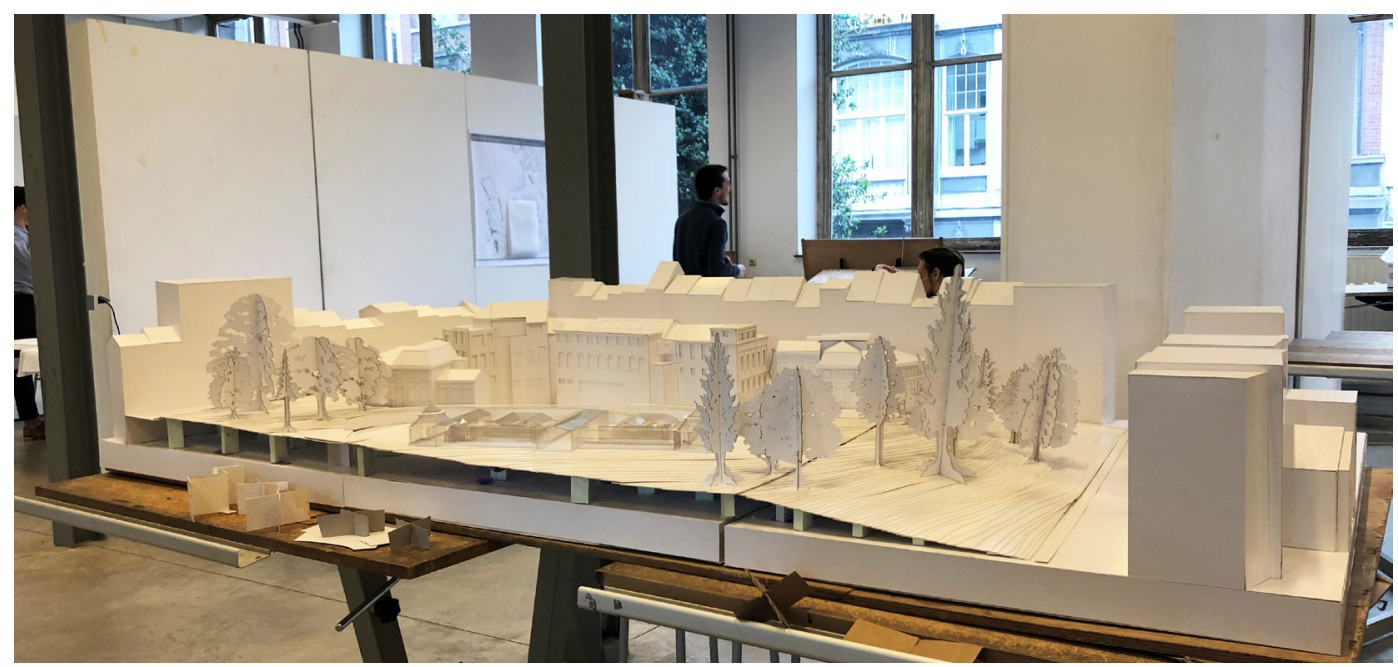

Fig. 3. Machetă de sit, anul 2, extinderea sediului Botanique al facultății de arhitectură din cadrul Uliège 
Atelierele verticale de Master promovează munca colaborativă în grupuri mici de studenți prin studiu în echipe în sensul împărtășirii abilităților elevilor la toate nivelurile (între M1 și M2, între studenții cu diferite cursuri opționale etc.). Este asumat faptul că prin lucrul în echipă studentul învață să-și găsească propria autonomie și învață totodată să aprecieze o adevărată cultură de atelier, aproape de viața în birourile de arhitectură.

Observarea site-ului și cercetările istorice au ocupat prima parte a semestrului 1 și au avut ca scop cunoașterea mediului și a locuitorilor săi, precum și documentarea problemelor actuale pe care le pune astăzi tipul de context studiat. Această etapă a condus la propunerea unei strategii de intervenție proprii fiecărei echipe urmând ca pe baza ei fiecare student să imagineze, argumenteze și studieze în semestrul 2 un program și un amplasament proprii, dar în legătură indisolubilă cu concepția de ansamblu. (fig. 4)

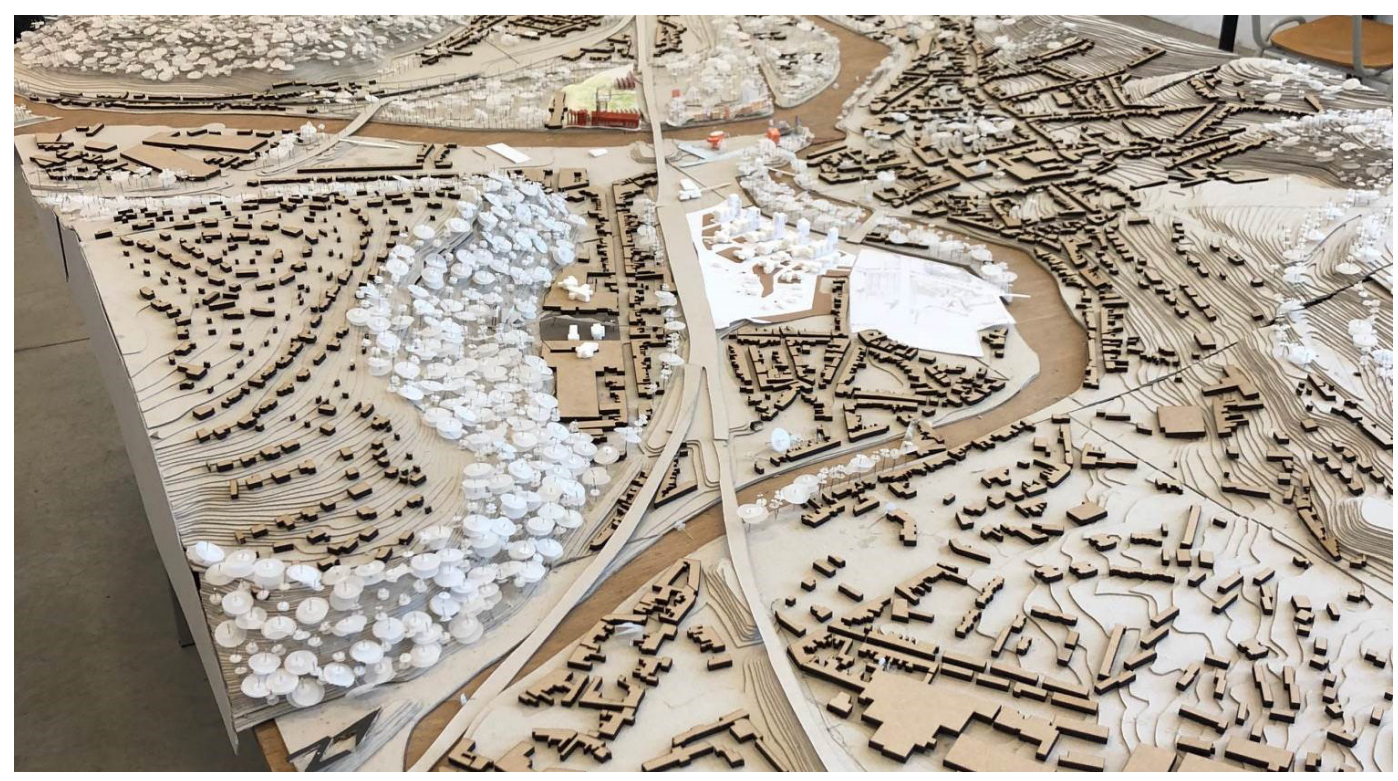

Fig. 4 Machetă de studiu, ciclu master

\section{CONCLUZII}

Observațiile prezentate mai ales în ceea ce privește metodele de predare sunt limitate la perioada scurtă de desfășurare a stagiului și la atelierele la care am participat, de aceea nu pot prezenta o imagine completă și obiectivă a școlii din Liège. Cu toate acestea am încercat să extrag o serie de similitudini și diferențe între cele două școli: Liège București. 
La nivelul de licență (anii 1, 2, 3) se observă un număr de similitudini atât în ceea ce privește:

- structura tematică în sensul unei acumulări gradate de cunoștințe și competențe, introducerea gradată a problematicii contextului (începând cu anul 2) și a problematicilor sociale (anul 3) și încheierea acestui ciclu printr-un exercițiu de sinteză abordând locuirea colectivă (anul 3 sem. 2);

- formarea culturii de specialitate, dezvoltarea gândirii critice și a reflexiei teoretice prin integrarea studiului sistematic al unor exemple de referință (anii 1 și 2);

- $\quad$ perioade de studiu mai scurte acordate exercițiilor dedicate anului 1 și extinse la perioada unui semestru pentru anii 2 și 3;

- $\quad$ studiul pe machete de sit și de obiect la scări diferite;

- $\quad$ abordări diferite și personale ale temelor între colectivele de îndrumare, atât la anii 1 și 2 dar cu precădere la anul 3.

Principalele diferențe se observă la ciclul de master:

- 5 ani de studii;

- ateliere verticale;

- $\quad$ ateliere tematice pentru proiectul de finalizare a studiilor.

Ceea ce trebuie subliniat ca principală diferență în ceea ce privește toți anii de studii este promovarea consecventă a unui grad sporit de autonomie a studentului, asumată de către toți profesorii (atât cei de atelier cât și de curs). Un alt element de diferențiere este asumarea declarată la nivelul școlii a rolului central al atelierului și o mai bună legătură între cursurile teoretice și atelier.

Ca observație finală aș vrea să compar gradul de implicare și interes al studenților pentru activitățile la care am luat parte care par să plaseze școala din București în avantaj.

Toate aceste observații, fragmentare și subiective, se așază într-o nouă lumină prin interviul pe care prof. Rita Occhiuto a avut amabilitatea să mi-l ofere în data de 10 octombrie 2020, interviu care vorbește despre o școală „în șantier”. 


\section{Preambul}

Conținutul acestor reflecții impune ca, în primă instanță, să considerăm că actuala Facultate de Arhitectură este rezultatul politicii de dezvoltare instituite de ULIĖGE la începutul anilor 2000.

Într-adevăr, în 2010,convergența celor două Institute Superioare de Arhitectură (ISA Lambert Lombard și ISA Saint Luc) emblematice pentru orașul Liège, a generat apariția celei de-a 11-a facultăți [de Arhitectură] din cadrul Universității din Liège. Timpul care s-a scurs până în prezent reprezintă o perioadă de tranziție, traversată de momente de revizuire internă, însă în mare măsură condiționată de schimbări profunde în cadrul Universității în sine. Până în anul universitar 2019- 2020, programele Master și licență erau rezultatul unei prime concertări între instituțiile inițiale. La începuturile sale, cercetarea a fost practicată și integrată în învățământ într-o manieră foarte diversificată.

Practica proiectului rămâne în centrul problemelor de dezvoltare specifică a arhitecturii. Între timp însă, corpul didactic nu a beneficiat nici de un loc în care să-și poată împărtăși experiențele, nici de oportunități de colaborare în ceea ce privește revizuirea și reînnoirea programelor.

Experimentarea continuă și includerea tuturor practicilor dezvoltate și în curs de dezvoltare, cât și „experiențele de colaborare” fac parte dintr-un „discurs teoretic", continuu contrazis de acțiunile de guvernanță actuale.

Anul în curs [2020-2021] marchează un moment de schimbare în programul de Master, ca răspuns la obligația europeană de a organiza toate programele de studiu în semestre. Reforma ciclului de licență este în curs de desfășurare, iar definirea unei oferte de formare doctorală pertinente, specifice arhitecturii, este încă destul de stângace.

Aceste reforme au constituit și un pretext pentru a răspunde unei politici universitare care pledează pentru interdisciplinaritate și pentru deschiderea către alte discipline. Ele au făcut obiectul unei reflecții mai aprofundate care, din păcate, nu s-a materializat.

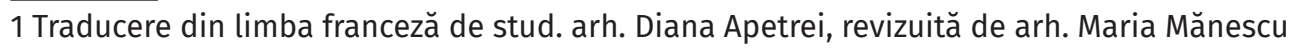


În acest context în schimbare am primit-o pe Melania Dulămea, conferențiar doctor arhitect. Răspunsurile la întrebările ce urmează sunt așadar, rezultatul unei „distanțări" față de circumstanțele schimbărilor în curs. Modificările programului de Master, ca și efectele schimbării culturale generice, sunt prezentate drept „condiții contextuale" ce deschid o reflecție privind nevoile și riscurile din cadrul învățământului și cercetării de arhitectură în zilele noastre, nu sistemul actual.

Această mărturie nu este deci o descriere a ceea ce suntem, ci mai degrabă o reflecție asupra a ceea ce am putea fi datorită bagajului cultural pe care îl deținem, deschiderilor și „metisajelor disciplinare” pe care arhitecturale practică dintotdeauna.

Melania Dulămea: Cum ați descrie profilul didactic al școlii dumneavoastră?

Rita Occhiuto: Contextul istoric în care ne-am format face ca profilul actual să fie cel al unei facultăți „în construcție”. Este vorba despre un șantier fără timp pentru experimentare și reflecție, aflat sub presiunea unui productivism științific, deseori acompaniat de consolidarea comunicării chiar înainte de verificarea calității produse. În această situație, facultatea este „oglinda” unei crize prin care trece în prezent arhitectura, ca disciplină și profesie deopotrivă.

Dimpotrivă, caracterul hibrid al arhitecturii, în prezent declinat în mai multe meserii, ar putea încă reprezenta un aspect ce ar trebui apărat, asociindu-l cu dorința de a dezvolta o identitate puternică, centrată pe „proiect”: proiectul ca mod de gândire, de lectură, de interpretare și de acțiune. Obiectivul major ar fi cel de a reafirma și de a face mai cunoscută experiența dovedită a unei discipline care, de-a lungul istoriei ei, nu a încetat să se confrunte cu altele, pentru a putea surprinde aspecte și practici pe care să și le aproprieze și să le integreze în propriile moduri de acțiune, care îi conferă aptitudinea de „a concepe și a crea spațiu”. Dat fiind că hibridizarea cunoștințelor este un demers vechi în arhitectură, în zilele noastre, școlile ar trebui să arate mult mai multă siguranță și încredere în realizările lor. Aceasta ar permite să facem față mai bine unei mișcări științifice care, prin redescoperirea interdisciplinarității, acționează adăugând puncte de vedere lipsite de timpi de hibridizare. Arhitectura este deja o disciplină hibridă și deschiderea sa către altele trebuie să constituie un atu, nu un risc de disecare și destrămare care să conducă doar la dezechilibru. Pentru reechilibrare trebuie însă timp, un factor care lipsește la scară largă practicilor actuale. De fapt, universitățile de astăzi pun în evidență rolul 
practicilor de gestiune managerială care, pe de o parte, pot contribui la rezolvarea anumitor chestiuni practice dar, pe de altă parte, atunci când afectează conținutul și temporalitatea predării, pot avea un efect devastator.

Aceste considerații sunt deci foarte importante pentru a înțelege dificultatea pe care o prezintă înființarea unei facultăți care se construiește în condiții de incertitudine, în mare parte generate de o criză mai generală a „Arhitecturii ca Artă și Disciplină”, istoric recunoscută. Acest aspect ar trebui să fie un element de coeziune care să fie utilizat în sistemul european de schimburi, nu prin plasarea într-o concurență comercială criminală, ci printr-un real sistem de colaborare care să protejeze o disciplină fragilizată, dar încă fondată pe capacitățile de sinteză și de aceea indivizibilă, indisociabilă chiar incomensurabilă, precum peisajul. (B. Lassus)

M.D.: Care sunt principalele preocupări legate de educație ale școlii dumneavoastră și cum se poziționează abordarea dumneavoastră pedagogică în privința acestora?

R.0.: Astăzi, facultatea tinde să răspundă, pe de o parte, la subiecte și teme legate de educație care se doresc a fi mai aproape de actualitate: tehnica se proclamă ca „studiu ambiental”, proiectul urban tinde să se dizolve în științele umane, în timp ce „practicile de scriere și reprezentare a spațiului" (definite astfel înainte de reformă) își pierd potențialul de cercetare devenind „instrumente și convenții de desen" aflate în slujba proiectului. Pe de altă parte, facultatea se „deschide” pentru alte facultăți: o deschidere care multiplică profilurile cadrelor didactice, în mod evident, dar care ar trebui susținută de practici mai puternice de colaborare. Acestea sunt mișcările unei facultăți care se schimbă repede.

În acest context în permanentă mutație, abordarea mea ar putea fi situată mai bine, întrucât experiența mea se referă la dezvoltarea de metode de proiectare care fac din arhitectură și contextul său medii de continuitate, unde acțiunile umane și naturale se află într-o continuă interacțiune. Echilibrele instabile, dar adaptative și flexibile care decurg de aici permit arhitecturii să răspundă mai bine provocărilor societale contemporane. Învățământul și cercetarea pe care eu le practic sunt fondate pe metode de lectură interpretativă care asociază istoria, morfologia urbană și peisagistica, dar și studiul sistemelor constituite prin semne și/sau scrieri întipărite în teritorii de către acțiunile antropologice sau geomorfologice.

Interesul privind,,site-specific approach" există, dar nu este suficient de cultivat și 
susținut în sistemul actual. Cu toate acestea, în noul program de Master, am propus dezvoltarea unei filiere mai specific legată de această hibridizare fructuoasă, care ar putea pregăti studentul cu potențial mai mare să conceapă arhitectura în simbioză cu mediile sale de inserție. Acest parcurs de formare academică ia numele de „PAYSARCH": Peisajul și Arhitectura ca un continuum. Dezvoltat pe durata celor doi ani de Master (4 semestre), acest parcurs oferă diferite momente de proiectare (cu dezvoltaretemporală variată): în primă fază, de a învăța să „parcurgă, să deseneze și să traducă în proiect", apoi să experimenteze, prin mai multe tehnici, și să execute, într-o manieră mai mult sau mai puțin construită, medii,„vii" (orașe și peisaje ca sisteme) prin programe de arhitectură care permit punerea în acord a așteptărilor cu ceea ce mediile naturale sau orașele existente mai pot încă accepta.

Acest parcurs face din arhitectură o artă de sine stătătoare ce permite tinerilor arhitecți să dialogheze cu experți provenind din mai multe discipline și culturi. Noi suntem la începutul acestui nou parcurs care s-ar putea dovedi un magnific generator de colaborare cu facultăți europene în care învățământul se bazează pe cunoașterea metodelor de lectură morfologică a arhitecturii și teritoriului și pe capacitatea de a face din desen o scriere interpretativă a mediilor noastre de viață.

M.D.: Facultatea de arhitectură din Liege este născută din fuziunea a două mari institute de arhitectură, Institutul Lambert Lombard și Institutul Saint Luc. Cum s-au integrat cele două structuri în noua facultate de arhitectură și cum beneficiază această din urmă de dubla experiență pedagogică? Puteți identifica câteva particularități care diferențiază facultatea pe care o reprezentați de alte numeroase școli superioare de arhitectură din Belgia?

R. O.: După o primă perioadă de structurare fondată pe o concertarea cunoștințelor și competențelor, facultatea a intrat în prezent într-o fază de adaptare la obiectivele generale ale Universității ULIEGE.Printre cele mai importante figurează interdisciplinaritatea practicată prin deschiderea facultății către alte discipline. Acest obiectiv este totuși practicat într-o manieră non nuanțată și constituie astăzi un risc de pierdere a specificității.

Pentru moment, reformele efectuate și cele care sunt în curs permit încă o readaptare a cunoștințelor și competențelor existente și prezervate de către vechile Institute Superioare de Arhitectură. Dar cunoștințele în materie de „reprezentare”, de „lectură a contextelor și orașelor" și a „istoriei spațialităților urbane și arhitecturale” sunt 
puse în pericol prin adoptarea de modele care analizează competențele universitare mai minuțios. În plus, metodele reflexive pe parcursul practicii artistice sau/și compoziționale riscă să fie slăbite.

Particularitățile care ar putea face o distincție între facultatea noastră și alte instituții de învățământ în domeniul arhitecturii din Belgia, rezidă în capacitățile de a forma în ceea ce privește concepția arhitecturală complexă, prin cursuri care deschid interesul pentru cunoașterea istoriei ca materie activă pentru pregătirea viitorului, cât și pentru practicarea desenului ca sistem de scriere pentru diferite tipuri de proiecte de arhitectură urbană sau peisagistică - concepute ca procese lente de mutație a teritoriilor. Arhitectura, considerată ca o practică trans-scalară a releveului, cunoștințelor și reinterpretărilor de medii (construite și neconstruite) locuite, era potențată de disciplinele cu care colabora. În zilele noastre, aceste continuități, chiar și recunoscute la scară largă, sunt mai dificil de aplicat. în plus, învățarea continuității dintre artefacte de arhitectură și natură sau între obiect și marele teritoriu ar trebui să poată fi susținută de o reînnoire a referințelor practicilor profesionale în curs.

Un mijloc de operare a acestor transformări ar fi favorizarea unei mai mari dezvoltări a cercetării prin proiect efectuată în cadrul facultăților de arhitectură, eventual în colaborare cu mediile profesionale și economice: un sistem de practică reflexivă ce nu trebuie inversată, care conferă formatorilor posibilitatea de a asigura evoluția meseriilor.

M. D.: După părerea dumneavoastră, care ar trebui să fie relația dintre învățământul de arhitectură și practică în lumea contemporană aflată într-o evoluție rapidă?

R. O.: Relațiile între învățământul și practica de arhitectură trebuie să rămână intense și variate. Modelul univoc al transmiterii cunoștințelor prin practică nu mai reușește să țină pasul cu mutațiile în curs de desfășurare. Unul dintre aspecte, încă puțin dezvoltat, se referă la rolul cercetării care, deși considerată necesară, întârzie încă să găsească acele căi ce ar putea fi recunoscute la scară largă. Prin cercetarea aplicată, practicată sub forma „cercetării prin proiect”, arhitectura generează practici reflexive care reconectează gândirea și teoria „de teren”. Observația, releveul și numeroasele metode de interpretare, textuale și de proiect, ne permit „să învățăm să învățăm”, plecând de la mediile existente. Caracterul iterativ al investigațiilor, urmat de ipoteze de mutații care trebuie să li se asocieze în timp, deschide căile ancorării în realitate 
Acest tip de acțiune reflexivă reduce distanța care poate exista între teorie și practicile proiectului. În plus, complexitatea crescândă a condițiilor antropice demonstrează că arhitectura se declină în mai multe tipuri de meserii, toate legate între ele.

Confruntată cu aceste schimbări, educația trebuie să conjuge practica și reflexivitatea prin moduri de concepție „circulară”, punând la încercare intențiile proiectului. Proiectul nu mai este un obiect, ci un sistem de elemente ce trebuie să evolueze în fiecare etapă de definire și execuție.

Pentru a atinge obiectivul unei practici reflexive mai fine și mai flexibile, timpul este factorul cel mai important ce trebuie regăsit: timpul cercetării pe teren, al jocului combinării și reconstrucției relațiilor, al testării fiecărei etape de realizare printr-o reflecție trans-scalară, atentă la păstrarea de legături puternice între vast și mic, între mineral și vegetal, între existent și reutilizarea sa prospectivă etc.

Acest tip de acțiune reconstruiește punți solide între moduri de chestionare a realului în cercetare și cele dezvoltate prin practica arhitecturală.

Contextele studiilor sunt aceleași: orașe și contexte peisagistice la diferite scări, modificate de acțiunile combinate ale omului și naturii. (Convenția Europeană a Peisajului)

Materialele lor sunt „acționate” simultan dinspre interiorul lor (mutația fizică a mediilor) și sub presiunea continuă a omului (un alt agent al transformării geomorfologice). Astfel, ca alternativă la modelul ce opune teoria practicii, se dezvoltă în prezent ipoteza unui mod de acțiune în care reflexivitatea pune în discuție realul și produce noi practici.

Aceste metode generează „proiecte scurte” care trebuie testate și revizuite periodic. Repetitivitatea acestui demers face din teorie un punct de consolidare a practicii, cu introducerea de posibilități diverse de reorientare a proiectului. Uneori, practica reflexivă permite atingerea unor rezultate mai performante decât cele obținute doar prin aplicarea experienței rezultate din practicarea meseriei.

Astfel, cercetarea se asociază proiectului, îmbogățindu-l cu faze succesive de concertare-revizuire și relansare, chiar cu locuri de monitorizare continuă (observatoarele) care cresc posibilitățile de a oferi soluții multiple și durabile. Aceste idei sunt reluate în Convenția Europeană a Peisajului care, adoptând teritoriul/ peisajul ca un câmp de interacțiuni multiple și în mutație continuă, deschide noi perspective pentru dezvoltarea de meserii legate de arhitectură mai fine, mai 
informate, mai performante, creative, inovatoare ...

Prin trans-scalaritate, aceste meserii tind să recompună ceea ce a fost fragmentat în secolul al XX-lea, mișcare ce repune în joc disciplinele și le estompează limitele. Încep astfel să reapară mișcări care hibridizează și termenii pentru o re-formulare sau o revizuire a continuităților, suprapunerilor sau tensiunilor posibile dintre arhitectură și peisaj (Landscape Architecture ), peisaj și urbanism (Landscape Urbanism), grădină și lume (Jardin Planetaire și / sau Landscape Gardening) etc.

În paralel cu mutațiile meseriilor, care se întrepătrund, forțând limitele arhitecturii până când devine context, Convenția cere universităților să-și extindă capacitățile de formare ca actor local, astfel încât să poată fi imaginată o formă interactivă de readucere în discuție și revelare continuă a teritoriilor care iau forma locurilor de observație și acțiune continuă (monitorizare a mutațiilor prin Landscape Observatories).

Toate acestea pun în evidență schimbarea profundă a practicilor care nu mai sunt dominate de tehnicitate. În mod contrar, confruntată fiind cu un caracter multiform și în mișcare al condițiilor teritoriale, arhitectura pare că poate reînvăța adaptarea, reziliența și flexibilitatea, reinterogând sistemele de mediu și peisagistice: studiul mutațiilor echilibrelor lor conferă o dimensiune dinamică modurilor de concepție arhitecturală.

Putem afirma în mod rațional că, în loc de a opune cercetarea practicii arhitecturale, este timpul să le reasociem pentru a susține evoluția „meseriilor de arhitectură” către forme mai adaptate la puternicele mutații pe care le suferă contextele de viață.

M.D.: Profesor Rita Occhiuto, dumneavoastră aveți o experiență importantă în cercetarea din domeniul arhitecturii peisajului; Profesorul Paul Hautecler are o experiență importantă în domeniul patrimoniului și restaurării. Conduceți împreună de mai mulți ani un atelier de arhitectură pentru Master. Cum este conturată strategia didactică pe care o practicați prin domeniile dumneavoastră diferite de expertiză ? Care este obiectivul principal al atelierului ?

R.O.: Atelierul proiectului de Master s-a născut din caracterul profilurilor noastre: suntem amândoi arhitecți de concepție, specializați într-un domeniu specific al arhitecturii; amândoi utilizăm metodele de lectură și descriere morfologică a arhitecturii și teritoriului ca limbaj, pentru a privi, decodifica, stabili legături / 
relații și a reconstrui relații între materialele contextelor existente; amândoi căutăm logici structurale cu ajutorul istoriei ca poveste, urmă și / sau imagine a locurilor investigate. Fiecare, în domeniul său de specializare, a făcut din cunoașterea și practica sa de arhitectură o bază de referință solidă pentru o repunere în discuție prin practica unei discipline surori ce permite reinterogarea continuă a relațiilor. Astfel, arhitectura peisajului a devenit o practică ce oferă posibilitatea de defragmentare a teritoriului prin re-legarea scărilor și modurilor de gândire, și care menține o preocupare atentă pentru proiect și calitățile spațiale în toate tipurile de contexte. Istoria peisajului și arhitecturii ni s-au oferit în mod rapid ca vectori performanți de cercetare a calităților și specificităților mediilor de intervenție arhitecturală.

Încrezători în convingerile și în practicile noastre reflexive, am construit învățământul bazat pe proiect în atelier ca cercetare pe teren.

„Conceput ca laborator de experimentare, atelierul este preocupat de evoluția locurilor în care mărcile istorice arhitecturale - urbane și peisagistice - oferă potențiale încă neexploatate pentru tratarea problemelor legate de calitatea habitatului și mediului, de identitate culturală, de structură a mediului construit și neconstruit, de valoare compozițională, de sedimentare istorică și geografică a siturilor, de temporalitate și ritmică diversificate.

Este vorba de problematici care permit studentului să-și dezvolte capacitățile de interpretare critică și conceptuală a arhitecturii, în scopul de a interveni în contexte complexe, în așteptarea proiectelor sustenabile. Evoluția meseriilor arhitecturale invită la o reorientare ciclică a instrumentelor și obiectivelor formării. Acest atelier oferă ocazia de a aprofunda studiul locurilor de implantare a limbajelor arhitecturale în scopul aprofundării cunoștințelor utile înnoirii continue a practicilor arhitectului." (Extract din programul anual)

Tematicile proiectului sunt alese plecând de la temele de cercetare studiate în laborator.Subiectul,spațiilorabandonateși/sau dezafectate, urbanesaupeisagistice" stă la baza unei reflecții parte a cercetării privind teritoriul orașului Liège. Aceste contexte care reprezintă uitarea și/sau refuzul au constituit instrumente puternice pentru: tratarea tuturor scărilor compoziției teritoriale; redescoperirea țesuturilor construite și ne-construite; evidențierea excepțiilor și persistențelor vechilor trasee sau amenajări care influențează încă scrierea teritoriului contemporan.

Metodele de lectură și scriere morfologică care combină orașul și peisajul au fost foarte importante pentru perfecționarea de strategii de proiect. Schematizarea relațiilor între construit și țesut, între straturile și materialele contextului, a permis 
regăsirea rațiunilor existentului. Texte, cuvinte cheie și reconstrucții schematice ale forțelor de acțiune în teritorii au permis punerea în operă a unor strategii care, în primă instanță, reconstruiesc trecutul locurilor, pentru ca ulterior să ofere strategii de recompoziție creativă a existentului: a parcurge, a cunoaște în profunzime, a-și re-apropria mental locurile la pas și prin desen, pentru a ajunge în sfârșit la o distanțare de urmele existente prin practica inventivă a semnelor și vocabularelor existente.

Mărcile materiale și imateriale ale locurilor au alimentat demersurile noastre complementare, voluntar orientate către o „reconstrucție simultan fondată și inventivă a relațiilor spațio-temporale ale existentului".

Gândirea bine fondată a consolidat reflecțiile și strategiile de reconstrucție inventivă a locurilor, prin enunțarea de argumentări ancorate cărora le potențează încărcătura expresivă, semnificativă și culturală prin operațiuni de rescriere inovatoare.

M.D.: Profesor Occhiuto, ați fost invitată de mai multe ori să faceți parte din comisiile de diplomă ale Universității Ion Mincu. În opinia dumneavoastră, în calitate de vizitator, care sunt cele trei calități principale pe care le puteți identifica în ceea ce privește școală noastră?

R.O.: Am apreciat mult curajul și perseverența de a menține solemnitatea momentului pe care îl reprezintă susținerea diplomelor. Cu toate acestea, mă îndoiesc de necesitatea întreruperii interacțiunii dintre profesor și student într-un moment atât de important și delicat. Evaluările de către un juriu din exterior constituie, desigur, un lucru bun, dar cu condiția ca părerile emise să poată fi recontextualizate și ponderate.

Calitățile majore pe care le-am putut recunoaște în majoritatea proiectelor evaluate se referă în primul rând la angajamentul și seriozitatea fiecărui student. Acestea devin vizibile prin importanța lucrării prezentate și, în cele mai multe cazuri, prin modul în care juriul este invitat să pătrundă în miezul proiectului, prin explicarea tuturor etapelor acestuia.

Calitatea mijloacelor grafice adoptate este foarte importantă. Fiecare proiect face obiectul unei preocupări deosebite pentru grafică. În majoritatea cazurilor, proiectul este foarte bine prezentat, printr-o abordare ordonată, de la scară teritorială și urbană până la proiectul de arhitectură și detaliile de execuție. Fiecare etapă este 
clar ilustrată și explicată.

Studenții dovedesc că stăpânesc aspectele obiective în ceea ce privește integrarea urbanistică.

Cu toate acestea, majoritatea anchetelor teritoriale se limitează la un descriptiv cantitativ care practic nu influențează aproape deloc proiectul.

Unele proiecte dovedesc o reală stăpânire a compoziției și inserției obiectului arhitectural în sit. Acest raport rămâne totuși puțin prea legat de aprecierea vizuală. Jocul scărilor comparate pentru a genera povești și/sau intenții noi de proiectare este foarte puțin practicat. Ceea ce explică, uneori, lipsa unei relaționări mai sensibile cu mediile investigate.

Calitățile compoziționale sunt importante, de asemeni și aspectele constructive.

Nivelul global de pregătire al studenților este bun și foarte bun.

M.D.: Și o ultimă întrebare, având în vedere că lumea întreagă traversează momente dificile din cauza pandemiei de Covid 19, credeți că experiența prin care trecem în aceste zile va schimba definitiv strategiile noastre de învățământ?

R.0.: La această întrebare nu pot răspunde decât prin exprimarea temerii că panica sanitară instalată ar putea constitui oportunitatea de a modifica profund desfășurarea atelierului de arhitectură, în sensul că ar putea fi redus la întâlniri prestabilite în videoconferințe. Am experimentat acest tip de întâlniri și am ajuns însă la concluzia că „modul de învățământ prin prezența fizică în atelier" este de neînlocuit în arhitectură.

La această constatare se adaugă urgența înțelegerii faptului că în arhitectură, ca și în peisagistică, învățarea se face prin experimentare practică. Această practică nu se referă doar la discuțiile din jurul unui desen ce trebuie corectat, ci, într-un mod mai general, la acest tip de învățământ în totalitatea lui.

Experimentarea practică și cea tehnică sunt ambele indispensabile.

Experimentarea prin intermediul parcursului, mersului și observației sensibile sau tactile a spațiului studiat este o practică ce trebuie consolidată. Într-adevăr, dacă, pe de o parte, arhitectura poate fi reprezentată într-o manieră imaterială prin intermediul noilor tehnologii, pe de altă parte, ea necesită practici care confruntă 
studentul cu materia, cu mediile în continuă mișcare, cu sunetele și alți factori de variație ai mediilor etc.

Doar contactul direct cu materia permite dezvoltarea privirii tactile și interesului pentru materiale și porozitățile lor, compactitatea, mai precis toate celelalte caracteristici care ghidează alegerea compoziției, precum și raporturile fluctuante între umbră și lumină.

În fine, atelierele sunt și locuri ale schimburilor de experiență, de cunoștințe și/ sau informații. A priva studentul de momentul experienței colective și de dezbatere generează o mare pierdere a calității.

Interviu realizat online de Melania Dulămea, 10 octombrie 2020

\section{REFERINȚE}

https://www.archi.uliege.be/cms/c_5634606/fr/archi-bachelier

https://www.programmes.uliege.be/cocoon/20202021/formations/descr/T1ARCH01.html https://www.programmes.uliege.be/cocoon/20202021/formations/descr/T2UARC01.html 